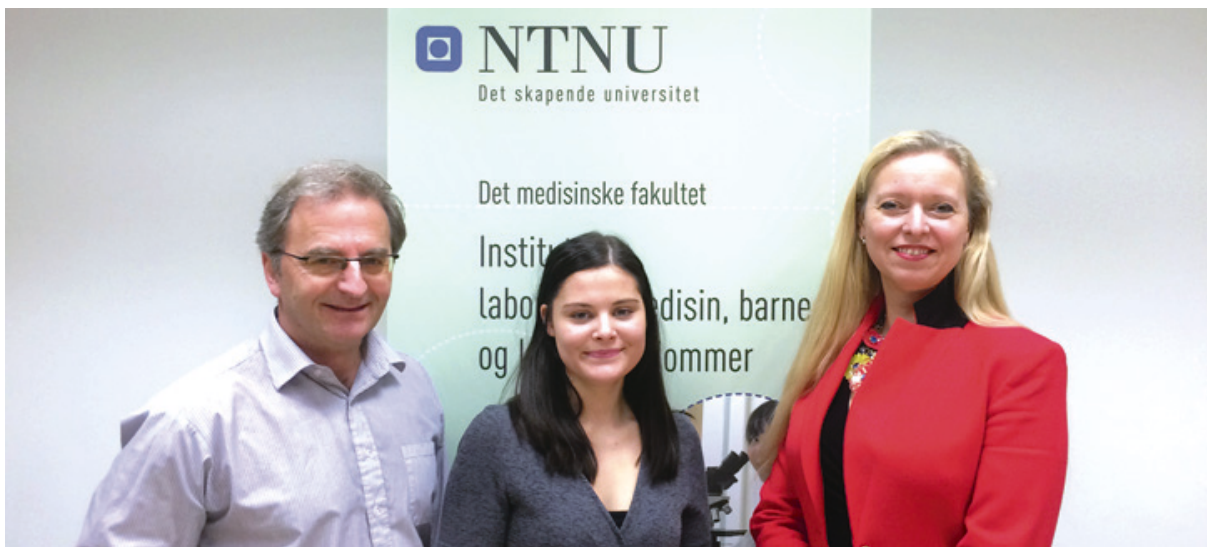

Førsteforfatter og medisinstudent Synne Aanes (i midten) sammen med sine veiledere Jon Skranes og Gro C. Løhaugen. Foto: Anne Elisabeth Sølsnes

\title{
Lav fødselsvekt gir dårligere hukommelse
}

Unge voksne som var for tidlig født med svært lav fødselsvekt har mindre hippocampusvolum og dårligere hukommelse enn andre jevnaldrende.

Hippocampus er en av de viktigste strukturene i hjernen for læring og hukommelse. For tidlig fødte med svært lav fødselsvekt, dvs. under $1500 \mathrm{~g}$, har økt risiko for hjerneskader i nyfødtperioden og avvikende hjerneutvikling og kognitive vansker senere i barnealderen. Tidligere studier viser at for tidlig fødte har lavere IQ sammenliknet med terminfødte når de når ungdomsalder. Det er også vist en sammenheng mellom mindre volum av hippocampus og redusert arbeidsminne hos for tidlig fødte. I en norsk studie, som nylig er publisert i NeuroImage, har man undersøkt hukommelsen og hjernestrukturen til unge voksne som var født for tidlig med svært lav fødselsvekt (1). Dette er Synne Aanes' første publikasjon.

Det ble gjennomført nevropsykologisk testing av hukommelse og MR av hjernen hos rundt 100 19-20-åringer. Av disse var 42 født for tidlig med fødselsvekt under 1500 g. Kontrollgruppen besto av 61 personer født til termin med normal fødselsvekt.

Som gruppe hadde de for tidlig fødte dårligere umiddelbar hukommelse, arbeidsminne og visuelt utsatt hukommelse enn kontrollpersonene. De hadde også mindre hippocampusvolum, selv etter kontroll for mindre totalt hjernevolum. Både hukommelse og hippocampusvolum var relatert til fødselsvekt og til hvor lenge barna hadde ligget på nyfødtintensivavdeling. De som var minst og sykest i nyfødtperioden, hadde dårligst testresultater og de minste hippocampusvolumene i tidlig voksen alder. Dårlig hukommelse hos de for tidlig fødte var også knyttet til mindre volum av hippocampus.

- Det observerte forholdet mellom mindre hippocampusvolum og redusert hukommelse kan indikere en sammenheng mellom struktur og funksjon av dette hjerneområdet, og kan skyldes avvikende og mangelfull utvikling og funksjon av hippocampus hos for tidlig fødte med svært lav fødselsvekt, sier Synne Aanes, som er medisinstudent og artikkelens førsteforfatter.

\section{Tverrfaglig samarbeid}

Studien ble gjennomført som en del av et pågående prosjekt, der man gjennom langtidsoppfølging fra nyfødt til voksen alder ser på hjerneutviklingen hos for tidlig fødte barn med svært lav fødselsvekt. Bidragsytere til dette prosjektet er Senter for tidlig hjerneutvikling (CEBRA), Institutt for laboratoriemedisin, barne- og kvinnesykdommer (LBK), Det medisinske fakultet og Norges teknisk-naturvitenskapelige universitet (NTNU) i Trondheim. Artikkelens førsteforfatter, Synne Aanes, er medisinstudent på femte året og går forskerlinjen ved medisinstudiet på Norges teknisk-naturvitenskapelige universitet. Studien er planlagt og gjennomført under ledelse av professor og barnelege Jon Skranes, professor emerita Ann-Mari Brubakk og postdoktor og nevropsykolog Gro C. Løhaugen. Testingen av deltakerne ble gjort av Løhaugen og analysene av MR-bildene ble utført av ph.d.-stipendiat Knut Jørgen Bjuland.

\section{Lise Mørkved Helsingen}

Tidsskriftet

\section{Litteratur}

1. Aanes S, Bjuland KJ, Skranes J et al. Memory function and hippocampal volumes in preterm born very-low-birth-weight (VLBW) young adults. Neuroimage 2014; 105C: 76-83.
Ordforklaringer

Hippocampus: En hjernestruktur i den mediale temporallappen som er en del av det limbiske system. Den spiller en viktig rolle for omdanningen av korttidshukommelse til langtidshukommelse og for romlig orientering.

Hukommelse: Evnen til å lagre og gjenkalle informasjon over kortere eller lengre tid. Deles inn i arbeidsminne levnen til å holde på og bearbeide informasjon over en kort periode) og langtidshukommelse levnen til å lagre og gjenhente minner).

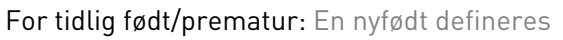
som for tidlig født, eller prematur, dersom fødselen skjer før fullgåtte 37 svangerskapsuker. 